\title{
Progressive realism and the EU's international actorness: towards a grand strategy?
}

\author{
André Barrinha a,b

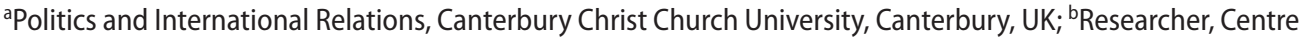 \\ for Social Studies, University of Coimbra, Coimbra, Portugal
}

\begin{abstract}
The EU lacks a coherent strategy to guide its international actions. This is a problem that has been amply discussed in both academic and policy-making circles, but that remains to be fully addressed. The December 2013 European Council recognised the issue, and the EU High Representative Federica Mogherini is in charge of a strategic review that will lead to a global strategy by June 2016. Most arguments in favour of a grand strategy rely on utilitarian arguments that highlight the EU's potential for a more efficient foreign policy. By linking a progressive realist approach to the importance of an EU grand strategy, this article intends to demonstrate the normative need for such a guiding document. As it will be argued, a grand strategy is a necessary step in the consolidation of the EU as a pluralist postnational polity that has in the fulfilment of its citizens' interests its raison d'être.
\end{abstract}

\section{KEYWORDS}

Classical realism; grand strategy; European external relations; normative power Europe; European security

Almost two and a half decades after Maastricht, and one after Lisbon, the EU remains an international actor attempting to assert its presence in the world. It sees itself and is often seen as acting according to high moral standards in the international stage; as a normative or civilian power that acts as a force for good (Manners 2002, 2008, 2015; Whitman 1998), but that ultimately lacks a comprehensive strategic approach to guide its actions (Edwards 2013). Neither the EU is able to act decisively in the world stage, nor do its member states have the capacity to do it alone (Menon 2014, 18). As an international actor, the EU acts in an ad hoc manner, too often with limited political results.

Unlike other works on the EU grand strategy (Howorth 2010; Smith 2011), it is not the aim of this article to discuss the details of what an EU grand strategy should include. Rather, this article intends, from a progressive realist perspective, to focus on the political relevance of creating one. In that context, it will be argued that, more important than the often discussed pragmatic reasons for the EU to adopt a grand strategy, there are reasons of normative stance that should be part of the discussion; reasons that relate directly to the EU's political raison d'être and to its condition of post-national pluralist polity. Only with a grand strategy, this 
article argues, can European citizens learn and contest the EU's vital interests ${ }^{1}$, i.e. can they actively exert their European citizenship. Methodologically, this implies developing a grand strategy based on more than the lowest common denominator between member states and the EU institutions; a grand strategy that Europeans and non-Europeans alike would take as the basis for the EU's role in the world; one with a political weight equivalent to US' National Security Strategy (Andersson 2015).

This problem was recognised in the December 2013 European Council when it was agreed that the high representative of the Union for Foreign Affairs should, together with the European Commission,

assess the impact of changes in the global environment, and to report to the Council in the course of $2015^{2}$ on the challenges and opportunities arising for the Union [...]. $(2013,4)$

The High Representative Federica Mogherini has undertaken a strategic review that has resulted in a number of reports, including a report on the current global strategic environment, a joint report with the Commissioner for Internal Market, Industry, Entrepreneurship and SMEs Elżbieta Bieńkowska on the European Defence and Technological Industrial Base and a report on the EU's activities in security and defence since December 2013. These last two were discussed at the Foreign Affairs Council in May 2015, while the report on the global strategic environment was presented at the European Council the following month, and constituted the basis for member states to request the high representative to 'continue the process of strategic reflection with a view to preparing an EU global strategy on foreign and security policy in close cooperation with Member States, to be submitted to the European Council by June 2016' (European Council 2015, 5).

As the paramount intellectual tradition in international relations, it would certainly be expected that the EU had been amply discussed within realism. However, not only those studying the EU rarely consider realism's theoretical insights (Rynning 2005, 4) as realist authors do not frequently engage with the problems and issues affecting the EU (Morgan 2005, 203; Peters 2010, 8). Maybe it is because realism brings a certain uneasiness to the 'dominant liberal values' associated with the EU (Hyde-Price 2007, 2). As a result, rather than being dominant, the realist literature on the $\mathrm{EU}$ is placed in a secondary position, rarely useful and often criticised for its inadequacy to the study of European-related matters: a Westphalian theory that does not belong to the post-Westphalian actorness of the EU (see Cooper 2004; Morgan 2005).

This article explores realism as a prescriptive, normative and progressive school of thought that has since the Second World War attempted to raise important ethical-political questions about the role of war and diplomacy in the international system; a tradition of thought that is inherently European, despite its American appropriation and transformation. A few other authors (Hyde-Price 2008; Rynning 2011) have used classical realist ethical ${ }^{3}$ arguments in favour of a prudent EU foreign and security policy. However, they have sufficiently explored neither the progressive dimension of classical realism (much less of its revival authors) nor the connection between the internal legitimacy of EU's actions and the importance of an EU grand strategy in that context.

Progressive realism is the label given by William Scheuerman ${ }^{4}$ to the political thought of authors normally associated with classical realism, such as Reinhold Niebuhr, Hans Morgenthau or John Herz. These are authors whose paramount concerns 'with the construction of a plural and vibrant public sphere' (Tjalve 2008, 7) were often forgotten in favour 
of the 'moral cynicism of power politics Henry Kissinger-style or [...] the rationalism of neorealist theory' (Tjalve 2008, 138). This label could also be extended to a recent generation of authors that brought back to life the theoretical, political and philosophical sophistication of these classical authors as an attempt to find answers or guidance, to some of the most prominent issues of our time: the global war on terror (Tjalve 2008), the obsolescence of the nation state (Scheuerman 2011) or the political and economic hegemony of liberalism (Booth 2011 and Williams 2005; 2011).

Applying this classical realism revival - or, as put by Sten Rynning, the 'return of the Jedi' $(2005,3)$ - to the study of the EU's international actorness involves framing the normative debate on the EU as an international actor in a realist approach that simultaneously highlights the perils and the need for a united Europe in the international stage. In particular, it intends to highlight how the EU's international actorness should be linked to the definition of a grand strategy that reflects both the interests of its people and the necessary restrains imposed by the interaction with the other actors in the international system.

Contra neorealism, it will be argued that an analysis merely based on the European articulations of power misses the constitutive importance the EU's external activities have in the development of a plural and democratic European polity. The definition of a grand strategy is here seen as a fundamental step to open up the debate about the EU's essential interests, and thus contribute to the progressive formation of a European public sphere. ${ }^{5}$ In a period of rising Euroscepticism, a grand strategy could be seen as a key step in bringing the EU closer to its citizens. In that sense, the development of a foreign policy that is based on the fulfilment of the EU's vital interests, defined according to the established needs and goals of the Europeans is a fundamental element in the constitution of a EU international actorness that is seen as legitimate both by its international peers, and by its own people.

Instead of directly focusing on realism's 'founding fathers', this article follows the above-mentioned intellectual movement of classical realism revival. The justification for this is simple: the intention is not to understand what Hans Morgenthau, E.H. Carr or John Herz had to say about the EU but (a) how the body of thought they have developed has been recently reinterpreted, and (b) how that reinterpretation can shed light on the current state of the European project, particularly in its international dimension. These scholars' reinterpretation of classical realist thought, offer a more accurate notion of how these 'classical' ideas were filtered by key contemporary International Relations' authors in their own right, such as Michael C. Williams and William Scheuerman. ${ }^{6}$ By looking into the reinterpretation of these texts, it is possible to disclose their'new truths that possibly open up for new political practices' (Pram Gad and Lund Petersen 2011, 321) and apply them to the study of the EU as an international actor.

In terms of structure, the article starts with a brief overview of the (mostly structural and neoclassical) realist literature on the EU and its foreign policy. From here, it delves into the works of contemporary classical realist authors assessing their motivations in rescuing the classical realist tradition and the resulting understanding of both the European integration project (this point will draw heavily from Scheuerman's work on global statehood) and the logic of its international actorness. The final section focuses on the importance of an EU grand strategy as a means to re-centre Europe's external priorities and to politically legitimise its actions next to its own citizens. 


\section{Realism and the European Union}

Whether understood as a 'discourse of disillusionment, motivated by the attempt to understand the horrors of the twentieth century' (Bell 2008, 7) or as 'the attempt, repeated and repeatedly failed, to translate the maxims of nineteenth century's European diplomatic practice into more general laws of an American social science' (Guzzini 1998, 1), realism is considered the dominant paradigm in International Relations. This disciplinary centrality has however led to its simplification and frequent construction of ideal types that attempt to merge different theoretical backgrounds into one 'theory', thus hiding important theoretical distinctions and nuances (Scheuerman 2010, 273) and over-simplifying the complexity of the theoretical contributions of key authors such as Carr, Morgenthau and Wight (Molloy 2006, 2).

Despite the underlying European cultural background to realism (particularly to its mid-century classical authors), it is the US structural realist 'version' that has been most applied to the EU (Hyde-Price 2007; Jones 2007; Rosato 2010). Neorealist authors (both in the defensive and offensive forms) usually understand European security as substantiated on an internal balance of power. ${ }^{7}$ For this realist literature, the EU serves three different purposes to its member states: it promotes their economic interests in the global economy; it helps them shape the regional milieu; and it 'serves as the institutional repository of the second-order normative concerns of EU member states' (Hyde-Price 2008, 31). In that sense, the $\mathrm{EU}$ is a mere institutional arrangement with a limited hold on core security issues, and its foreign policy is 'little more than the sum of its parts' (Bickerton 2011, 172). The integration process was, following this approach, only possible due to the strong US presence in the continent (Hyde-Price 2007, 67). Without the US security umbrella, the European project would have fallen apart (Merlingen 2012,13) and 'Europe would go from benign bipolarity to unbalanced multipolarity' (Mearsheimer 2001, 52). ${ }^{8}$

Another common claim among neorealists is the idea that the EU can constitute an alternative pole of power (Posen 2006)..$^{9}$ According to this argument, the EU plays the double game of being able to be autonomous from the US (and therefore a potential alternative pole of power in the international system) when their interests are not coincidental, while also being able to leverage its influence in Washington by showing it is capable of going alone (Art 2004). Even if flattering for the EU, such assumptions would be in stark contrast with the recent past, as recognised by Art himself when mentioning the EU's incapacity to decisively intervene in any of the Balkans' wars (Art 2004). In reality, when it comes to balancing, the EU would have to be seen as a below par competitor of the US. More than two decades since the creation of the Common Foreign and Security Policy there still is, using Hill's (1993) famous expression, a 'capability-expectations' gap in Europe (see Stokes and Whitman 2013; Witney 2008).

While these realist accounts re-centre the issue of power into the studies of EU's external relations, they do fail to go much beyond neorealism's parsimonious explanatory value. For them, it is the balance of power (or interests, or threats, depending on the realist author one follows) that ultimately defines the EU's (or the EU great powers') actions in the international stage.

More recently, there have been a few works linking the EU to what is known as neoclassical realism (Costalli 2009; Dyson 2010). The neorealist view(s) on the EU and particularly its security and defence policy are not necessarily coincidental with the neoclassical take on the subject (see Dyson 2010). Despite sharing the neorealist positivist approach to science, 
neoclassical realism attempts to reconcile some of the aspects highlighted in classical realism with neorealist theory. As argued by Tom Dyson, it 'combines neorealism's emphasis on the "survival" motivation of states, with classical realism's focus on the dependence of political leaders on domestic society for material resources and support for foreign and defence policy goals' $(2010,120)$. Thus, even though neoclassical realists maintain that states are conditioned by the structure of international anarchy in their foreign policy assessments (Costalli 2009, 327), they also understand 'that people and institutions with long and complex histories (the intervening variables) actually make policy' (Rynning 2011, 33), and that these intervening variables mediate between power pressure and agency (Costalli 2009, 327).

Neoclassical realism could, in that regard, be understood as an improvement in terms of its ability to explain the EU internal and external dynamics. However, its capacity to introduce a political-ethical assessment of the EU as an international actor remains very limited. Here, classical realism has a clear advantage over its 'neo' successors. Even authors sympathetic with neorealism such as Hyde-Price, need to go back to classical realist authors, focusing on the need for prudence, scepticism and reciprocity when attempting to advance beyond this explanatory field (Hyde-Price 2008, 42). However, by attempting to bring together the classical ethics of prudence with a neorealist understanding of the world, Hyde-Price falls in an ontological and epistemological trap that places under the same label two opposite understandings of the world, theory and agency. It blends the 'is' and 'ought' (Snyder 2011) common in classical realism that Waltz (1979) carefully tried to set apart in his Theory of International Politics. For, even though Waltz's neorealism is based on features common to classical realism, such as the notion that states are bound by power imperatives (Dyson 2010, 97) ' [b]y making structural power the independent variable, one is not only bracketing all the stuff of classical thinking as "intervening" but employing the language of causal theory that classical realists abhorred' (Rynning 2011, 34).

\section{Progressive realism and Europe as an international actor}

'Classical' realism is a nebulous theoretical ensemble that attempts to understand the world as it is, with the crudity of power as its essence, but with significant ethical concerns in what regards the evolution of the international system. These were (and still are) often prescriptive positions attached to strong political (E.H. Carr) and, in some cases, ethical (Reinhold Niebuhr) commitments, whose normativity would be seen by contemporary realists as too non-scientific or even speculative. Contrary to the scientific accuracy of neorealism, '[t]here are no fixed answers in classical realism. Insights are interpretive and historical and by definition contextual' (Rynning 2011, 32). To an extent, classical realism is more of a normative approach than an explanatory theory, one that 'holds power to be a permanent source of temptation' (Tjalve 2008, 143). More than constructing a specific theory of how the world works, classical realism presents particular historically and philosophically informed readings of how the world should work and what happens when it does not work as it should; readings concerned with the potential clashes between (and limitations of) international law, morality and politics.

Authors such as Hans Morgenthau, Reinhold Niebuhr, John Herz or E.H. Carr coined and developed concepts such as national interest, balance of power and security dilemma, but they did not 
promulgate a cramped view of the national interest, embrace a backwards-looking and institutionally conservative model of the balance of power, or see the security dilemma as an insurmountable barrier to international change. (Scheuerman 2011, 15)

As explained by William Scheuerman, most of these realist authors were linked to progressive political movements. Even Morgenthau, who'never shared his Frankfurt colleagues' enthusiasm for Marx' had sympathy for their social and economic reformist ambitions $(2009,24)$. Whereas these were, in Scheuerman's view, progressive realists, Michael C. Williams prefers to use the expression 'wilful' to describe the work of these same authors. In his own words,

Wilful Realism is deeply concerned that a recognition of the centrality of power in politics does not result in the reduction of politics to pure power, and particularly to the capacity to wield violence. It seeks, on the contrary, a politics of limits that recognises the destructive and productive dimensions of politics, and that maximises its positive possibilities while minimizing its destructive potential. $(2005,7)$

It is a realist approach that attempts to balance power, politics and progress; a realism that does not shy away from the tragedy of politics, while simultaneously acknowledging its true emancipatory potential. In spite of some ambiguities in their arguments - mostly related to the mid-century US academic context (see Wæver 2011) - authors such as Hans Morgenthau were strong opponents of a purely rational and empirically driven understanding of politics (Williams 2005, 5). Additionally, they advocated the establishment of relational processes (Williams 2005,6 ) between different polities that was translatable into'a modus vivendi and engagement between contrasting values and forms of life' (Williams 2005, 208). Finally, they did not eschew the dilemmas of power politics. They had a deep understanding of the constant tension between power and morality, and not only material power but also ideational.

It is in the rejection of absolute truths in politics, in the need to engage with the other and in the acknowledgement of the limitations imposed by power that these authors understand the possibility of change. Indeed, '[t] heir "wilfulness" resides in their unflinching attempts to construct a viable, principled understanding of modern politics, and to use this understanding to avoid its perils and achieve its promise' (Williams 2005, 9). Rather than promoting a politics of fear as often depicted, 'classical realists such as Morgenthau sought to counter and restrain the role of fear and enmity in political life rather than embracing it' (Williams 2011 , 458). Theirs was a politics of plurality and critical judgment (Williams 2010, 657), for which it was essential to formulate clearly defined political interests.

Power is bound by the interaction of different national polities' interests. Interests, rather than merely power, define the balance of the international system (Rynning 2005, 18). The constitution of those interests is defined by a political game centred on political decision-makers but open to a general audience that debates and questions those previously defined political options. In that sense, interest is an important conceptual tool to understand how the world is politically constructed. However, it is also a normative concept, in that it specifies the need for plurality, both international (as it necessarily acknowledges the diversity of national interests) but also internally, as it results from, or is at least influenced by the internal plurality of a given political entity. Particularly in Williams' reading of Morgenthau 'the national interest functions as a self-reflexive concept, and a sophisticated analytic and rhetorical device attempting to mobilise civic virtue and support a politics of limits' (2005, 11). This is the place where power and political openness meet (Williams 2005, 9) as there is a transcending dimension to its definition: '[t]o ask what the nation's interests are, is to ask what the nation itself stands for' (Williams 2005, 187). As mentioned above, when applied 
to the EU, rather than discussing 'national' interest we could discuss 'European' interests, those that can only be competently addressed - issues related to climate change, financial regulation or border management would clearly fall within this category - through a European collective effort, and that in return defines what Europe stands for. Other authors have different views about this. For instance, Nathaniel Copsey, reduces Europe's interests to four elements: promotion of its values, particularly peace; open markets; multilateralism; and democracy and the rule of law $(2015,187)$. Although these are commendable goals, they can all be subsumed under the promotion of a liberal agenda. They tell us very little about the political priorities Europe should assume and the policies it should adopt in its engagement with other leading actors' interests. One could even argue that today's difficult relations with Russia are in part to blame due to the EU's pursuit of this liberal agenda.

A foreign policy that acknowledges the plurality of national interests is a foreign policy that recognises the existence of alternative views and values. By recognising them, it is easier to avoid indulging in universalistic quests or in reckless foreign policy initiatives that intend 'to radically transform the world' (Bell 2010,98). Prudence is thus a second key concept in the classical realist lexicon. Prudence brings together a polity's national interest and its principles as 'the prudent actor will be attentive to the ways in which his own political community results from a complex political history, a recognition that allows for a more balanced and less "moralistic" foreign policy' (Lang 2007, 19). In a world in which the EU is often portrayed as either the champion of universal normative ambitions or as an actor incapable of translating its economic robustness into meaningful political power, prudence comes as an important political principle that highlights both the dangers of inaction and the problems of what Morgenthau would call the 'crusading spirit' (1993 [1948], 381). Finally, a foreign policy based on a prudent national interest is most likely based on both an internal and an external legitimacy as a policy that has the support and/or consent of the domestic and international public opinion is certainly a policy with a higher chance of success. In that sense, interest, legitimacy and prudence are three key principles that should successfully guide the action of a political entity in the world stage.

The problem for progressive realists already in the late 1940s was that they saw the state as increasingly incapable of advancing the interests of its citizens and incompetent to deal with the paramount issues in the international agenda (such as the recurring threat of nuclear war), most of which were transnational in character. Different political entities and solutions were needed, particularly in Europe, the cradle of the most destructive wars in the history of humankind.

Despite the state-centric language, many realist authors were, particularly after the Second World War, involved in an intellectual debate regarding the viability of a world state, arguing in favour of alternative conceptions of human government, distinct from the increasingly obsolete nation state (Scheuerman 2009, 2011). Others were directly involved in promoting the European integration process, as was the case of Raymon Aron. ${ }^{10}$ The development of nuclear weapons (see Craig 2003) and the increasing identification of transnational problems meant that international relations were becoming too important to be left to states.

As extensively discussed by William Scheuerman, there was no necessary consensus on the form this global reform process should assume. For both E.H. Carr and Niebuhr, the solution was a regionally based approach (Scheuerman 2011, 76-79). Hans Morgenthau, on the other hand, had an open mind regarding the adoption of cosmopolitan projects (Scheuerman 2009, 116), but was particularly sceptical of a supranational Europe as it 
could end up 'reproducing the moral pathologies of existing nation states' (Morgenthau in Scheuerman 2011,53). Functionalism was perceived as a provisional way out for this dilemma with Morgenthau and other realists praising David Mitrany's A Working Peace System (1946). As stated by Scheuerman echoing E.H. Carr (but also Morgenthau),

[f] unctional organization not only contributed to the creation of a postnational society which alone might successfully undergird stable political organization beyond the nation-state; it also checked potentially dangerous centralizing tendencies. $(2010,261)$

Additionally, it also had the ingredients for the establishment of post-national cooperative relations that could cut across multinational blocs, thus preventing the division of the world along large polities that would degenerate into empires responsible for even worse atrocities than what had been seen during the Second World War.

In that sense, the European integration project could be understood as containing the seeds for both the world's destruction and its post-national future. By following a functionalist path, Europe was creating the possibility of generating a post-national society that could then evolve towards a post-national sovereign. That, however, could only result from 'an act of will' (Scheuerman 2011,91) and not as some sort of spin-off of economic and social cooperative mechanisms devised under the functionalist Schuman Plan. Such act of will is still to be accomplished. A European grand strategy would be an important step in that regard.

\section{The EU, grand strategy and the possibility of politics}

A grand strategy results from a political act that 'entails calibrating means and ends, capabilities and objectives, on the basis of an understanding of the structural context within which the actor is situated' (Hyde-Price 2007, 46), leading to 'the definition and ranking of preferences, i.e. goals and objectives' (Hyde-Price 2007, 46). Its 'overarching strategic aim must be to establish a societal order that can respond to social and political challenges with a minimum of warfare' (Neumann and Heikka 2005, 13). It ultimately stands for its values and serves the materialisation of its interests. In that context, an EU grand strategy could be understood 'as a general plan for, or process of, integrating the policies and resources of the EU to protect and advance its core or vital interests' (Smith 2011, 147).

The last decade has seen the EU approve a significant number of documents labelled as strategies (e.g. EU Counter-Terrorism Strategy, EU Internal Security Strategy, EU Cyber Security Strategy, EU Maritime Security Strategy - see Edwards 2013 for a critique). From all of those, the 2003 European Security Strategy would arguably be the one that more closely resembles a grand strategy. The so-called Solana document is an important element in the building up of the EU's international profile. However, it does not identify any clear value and interests that it should defend (Biscop et al. 2009, 9). Additionally, it does not attempt to combine the different elements and policies of the EU in the definition of a strategy that safeguards what its member states are no longer able to do on their own:'at the global level, all Member States are small States' (Biscop et al. 2009, 16). Finally, it is clearly outdated and does not consider institutional innovations, such as the creation of the European External Action Service (Emmanouilidis 2011, 195). With the absence of a grand strategy, the EU fails to have a document that codifies the fulfilment of its vital interests (Biscop and Coelmont 2011) and the tools to accomplish them in the world.

As it stands, not only the EU does not have a grand strategy, as the document that most closely resembles one, the 2003 European Security Strategy, puts forward a groundless normative 
vision of the EU's international actorness arguing that, for instance, when acting together with the US, both the EU and the US can be 'a formidable force for good in the world' (European Council 2003: 13). The idea of being a 'force for good', or a 'normative power' (Manners 2002) is certainly something that contradicts any classical realist reading of what the EU should be and do. As argued by Rynning, classical realists would worry that this 'may result in reckless policy' $(2011,35)$ devised without the clear definition of a grand strategy, and with a significant 'democratic deficit' (Bickerton 2007, 25). As Chris Bickerton accurately points out, 'there is no unified foreign policy that pursues a pan-European interest and that draws its forward momentum from a direct connection with a European "people"' $(2007,37)$. Stanley Hoffmann highlights this last point when referring to how the EU defines its security policy:

Although diplomacy comes traditionally 'from the top', security policy requires a public consensus; but 50 years after the Schuman plan, there still is no 'European public space' - there is only a juxtaposition of national public spaces, capped by a jumble of intergovernmental and supranational bureaucracies. $(2000,198)$

The absence of a grand strategy where the EU's vital interests are clearly identifiable in, and from which it is possible to establish a process of permanent self-reflection and critique, means the EU lacks a firm ground from which to define its international actorness and its citizens lack a clear guideline from which to judge its actions.

An EU grand strategy would act as a political viewpoint for its citizens as, quoting Vibeke Tjalve,'only when a political system defines clear political viewpoints may counter-views be provoked' $(2011,446)$. In the EU's case, that demands a thorough exercise of identification and prioritisation of Europe's interests (Copsey 2015, 187). But how far has the EU gone in that regard?

\section{A window of opportunity}

As mentioned in the introduction, member states have decided in December 2013 to trigger a process that could, potentially lead to a more robust and encompassing strategic framework. The world (and the EU) has significantly changed since 2003, and the current geopolitical context seems to dictate the need for a strategic review. The May 18th Foreign Affairs Council Conclusions on CSDP highlight the instability in the EU's vicinity - from Libya to Ukraine - together with emergence of new security challenges as justifications for the EU to assume 'increased responsibilities to act as a security provider, at the international level and in particular in the neighbourhood' (Foreign Affairs Council 2015, 2). In that regard, it welcomes the ongoing strategic review that could potentially lead to a 'broad European strategy on foreign and security policy issues' that could 'identify and describe EU interests, priorities and objectives, existing and evolving threats, challenges and opportunities, and the EU instruments and means to meet them' (Foreign AffairsCouncil 2015, 2).

According to the high representative, the review 'will cover the context against which the level of ambition can be set, taking account of interests and values, the overall security environment, the consequent need to project force and the available resources.' (High Representative 2015, 2). Both the changes that have been introduced with the new Commission (such as the creation of the Commissioners' Group on External Action, bringing together different DGs involved in the EU's external relations) and the Action Plan on the EU's Comprehensive Approach, highlight the EU's intention of becoming a more coherent actor in the international stage. The ongoing strategic review is very much seen within that 
context. From a progressive realist perspective, we could identify three main challenges to this process and eventual outcome that if unaddressed will mean the 2016 Strategy will be as weak as its 2003 version.

The first challenge has to do with the current political climate in Europe. The electorate in many European countries is quite sceptical of any new EU-related initiatives and national governments are obviously weary of being seen as too pro-European. ${ }^{11}$ This has deep implications for both the development of a strategy and for its materialisation. Although there seems to be an EU-wide consensus that a new strategy is needed, there is the strong possibility that such a document will not be more than a collection of general remarks and toothless assertions that do not link the EU's external activities to any clear notion of European interest and that, when materialised, will not lead to any significant commitment from member states. The balance between taking on board the interests of 28 member states while focusing on the holistic European interest will thus be a key exercise.

Second, in order to become a central document in European politics, the new strategy needs to be embedded in the EU's regular political process. As it stands, the current strategic review is completely ad hoc, both chronologically and procedurally. For Europeans to be able to engage with it, they need to understand its importance and purpose; they need to see the EU as an actor with a strategic vision. That is what, for example, the US National Security Strategy is primarily for Andersson $(2015,1)$. As written by Antonio Missiroli, the current director of the European Union Institute for Security Studies,

an increasing insecure European public is being bombarded by simplistic messages and unrealistic slogans. All external policies begin at home. They need to be supported by a public opinion which is better informed of the nature of the risks the EU is confronting and the response that may be necessary to main the achievements of the past decades and defend both our interests and our values. $(2015,4)$

This process of clarification is not something that can only happen whenever member states decide to create or update a strategy; it needs to be a continuous one.

Finally, the current strategy needs to be seen as the cornerstone of all the EU's political activity. Specialised strategies should derive from it and national strategies should have it into due consideration. Otherwise, it will just be one among many European documents with limited value.

A strategy of vague lowest common denominators would be a missed opportunity to provide some grounding to the EU's actions in the world and, more importantly, to offer a solid basis for the European citizens to perceive, discuss and contest the priorities and interests that should guide the EU as an international actor. From this perspective, the current process of defining a global or grand strategy acquires a quasi-existential importance for the future of the European integration process.

\section{Conclusion}

This article attempted to bring the latest research on classical realism to the debate of the EU's role as an international actor. Its starting normative concern was very much in line with Nathaniel Copsey's when he refers to the 'imperfect' European integration as offering 'the peoples of Europe their best, indeed only, change of being able to cope successfully with the big-picture economic and global challenges that they are facing in the twenty-first century issues [...]' $(2015,163)$. 
As we had the opportunity to see, there is a progressive and normative element in authors such as Carr, Morgenthau or Niebuhr that had been partially silenced by neorealism, rephrased by neoclassical realists, and eventually fully recovered by authors such as Scheuerman and Williams that can contribute to expose the political and ethical limits of the EU's external action. In the absence of clearly defined interests, and of a grand strategy that outlines them, the EU acts and intervenes according to the moment, usually dependent on US policy, and without the recognition, debate or approval of its citizens. The identification of when and where to act is set independently of any notion of European interest.

Contrary to the EU's current practice, there is a thread that links grand strategy, interest and legitimacy that needs to be considered as a whole. The EU's external relations should be entirely based on the fulfilment of those interests. In the same vein, such interests cannot be the result of closed-door sessions with experts, but rather of an intense European-wide debate. According to Vibeke Tjalve, for authors such as Morgenthau and Lippmann, it was fundamental in the US of the Vietnam War years to 'resurrect a new attitude amongst the public, which viewed civic participation and critique as a necessary and constructive development' $(2008,124)$. Considering that we live in a period in which 'there is uncertainty about the Union's new raison d'être' (Emmanouilidis 2011, 182), such steps may well be fundamental for the future survival of the European project.

\section{Notes}

1. According to Biscop and Coelmont, '[v]ital interests are those that determine the very survival of the EU's social model, which is based on the core values of security, prosperity, democracy and equality' $(2011,17)$.

2. The Foreign Affairs (Defence) Council has set April 2015 as the deadline for the report $(2014,4)$.

3. Following Joel H. Rosenthal, ethics is here understood as 'the process by which sources of morality (or traditions) are digested and applied to problems of the social world' $(1999,3)$.

4. According to Scheuerman, this category'not only aptly sets this group of mid-century Realists apart from the politically and institutionally conservative Realism of, say, Butterfield or Kissinger, but it also properly highlights the neglected institutionally reformist and oftentimes left-leaning political character of their rich body of thought' $(2011,7)$.

5. For more on the concept, see Habermas (2001) and Risse (2010).

6. As argued by the former, " $[t]$ he interpretation and use of "classical" thinkers in intellectual and political debate is never a wholly innocent process. It always reflects its historical genesis and context of current concerns' (2007: 5).

7. As argued by Robert Art's analysis of the immediate post-cold war context in Europe: 'the multiple actors bearing on Europe's security policies, the importance of national interests and differing perspectives, and the hedging policies toward the US, Russia, and Germany - represent the important underlying forces that have shaped balance of power considerations in Europe's security policies since $1990^{\prime}(2004,186)$.

8. John Mearsheimer's prognosis has by now been discarded (Hyde-Price 2007,4) as'an ahistorical view of Europe that is not equipped to critique political realities or the compromises between power and morality' (Kenealy and Kostagiannis 2013,226), but one is certainly left thinking whether, in the context of the current European political crisis, we are moving dangerously closer to his prognosis: 'The United Kingdom, France, Italy, and Germany would have to build up their own military forces and provide for their own security. In effect, they would all become great powers, making Europe multipolar and raising the ever-present possibility that they might fight among themselves. And Germany would probably become a potential hegemony and thus the main source of worry' (Mearsheimer 2001, 52). 
9. As Barry Posen concludes in his pessimistic understanding of European security:'Should ESDP progress, as it well might, given the causes at work, it seems likely that Europe will prove a less docile ally of the US in a decade or two' $(2006,186)$.

10. Aron, according to Daniel Mahoney, 'recognized that a united Europe must be political, that it must be able both to defend itself and to carry out serious global responsibilities' $(1992,134)$.

11. As pointed out by Nick Witney et al. 'With the financial and economic crisis far from over, introspection, defensiveness, and mutual resentments colour the outlooks of too many member states' $(2014,6)$.

\section{Acknowledgement}

The author would like to thank Zeynep Arkan, Erin Baumann, Sven Biscop, Tom Dyson, Geoffrey Edwards, Bruno Oliveira Martins, Jocelyn Mawdsley, Sara Ramos Pinto, Munevver Cebeci, Licinia Simao and Daniel Smith for their valuable comments and critiques on earlier drafts of this paper.

\section{Disclosure statement}

No potential conflict of interest was reported by the author.

\section{References}

Andersson, J. 2015. Talking strategy: Washington's new NSS. Issue Alert, EU-ISS 9: 1-2.

Art, R. 2004. Europe hedges its security bets. In Balance of power revisited: theory and practice in the 21st century, eds. T.V. Paul, J. Wirtz and M. Fortmann, 179-213. Stanford: Stanford University Press.

Bell, D. 2008. Introduction: under an empty sky - realism and political theory. In Political thought and international relations. Variations on a realist theme, ed. D. Bell, 1-25. Oxford: Oxford University Press.

Bell, D. 2010. Political realism and the limits of ethics. In Ethics and World politics, ed. D. Bell, 93-110. Oxford: Oxford University Press.

Bickerton, C.J. 2007. The perils of performance: EU foreign policy and the problem of legitimization. Perspectives. The Central European Review of International Affairs 28: 24-42.

Bickerton, C.J. 2011. Towards a social theory of EU foreign and security policy. JCMS: Journal of Common Market Studies 49, no. 1: 171-90.

Biscop, S., and J. Coelmont. 2011. Europe deploys towards a civil-military strategy for CSDP, Egmont paper 49. Gent: Academia Press.

Biscop, S., Andersson, J. J., Coelmont, B., Coolsaet, R., Emmanouilidis, J. A., Grevi, G., Howorth, J. M., Mattelaer, A., Quille, G., Renard , T., Versmessen, B., and Whitman, R. 2009. The Value of Power, the Power of Values: A Call for an EU Grand Strategy, Egmont Paper 33. Gent: Academia Press.

Booth, K. 2011. Realism redux: contexts, concepts, contests. In Realism and World politics, ed. K. Booth, 1-14. New York: Routledge.

Cooper, R. 2004. The breaking of Nations. Order and chaos in the twenty-first century. London: Atlantic Books.

Copsey, N. 2015. Rethinking the European Union. London: Palgrave.

Costalli, S. 2009. Power over the sea: The relevance of neoclassical realism to Euro-Mediterranean relations. Mediterranean Politics 14, no. 3: 323-42.

Craig, C. 2003. Glimmer of a new Leviathan. Total war in the realism of Niebuhr, Morgenthau, and Waltz. New York: Columbia University Press.

Dyson, T. 2010. Neoclassical realism and defence reform in post-cold war Europe. Basingstoke: Palgrave Macmillan.

Edwards, G. 2013. The EU's foreign policy and the search for effect. International Relations 27, no. 3: $276-91$.

Emmanouilidis, J. A. 2011. The leitmotiv of a global Europe. In The delphic oracle on Europe. Is there a future for the European Union?, eds. L. Tsoukalis and J.A. Emmanouilidis, 181-202. Oxford: OUP. 
European Council. 2003. A secure Europe in a better World. European security strategy, Brussels, 12 December.

European Council. 2013. Conclusions, EUCO 217/13, Brussels 20 December.

European Council. 2015. Conclusions, EUCO 22/15, Brussels 26 June.

Foreign Affairs (Defence) Council. 2014. Council conclusions on common security and defence policy, Brussels, 18 November.

Foreign Affairs (Defence) Council. 2015. Council conclusions on common security and defence policy, Brussels, 18 May.

Guzzini, S. 1998. Realism in international relations and in international political economy. The continuing story of a death foretold. London: Routledge.

Habermas, J. 2001. Why Europe Needs a Constitution. New Left Review 11: 5-26.

High Representative. 2015. HRVP/head of the agency report ahead of the June 2015 EC, Brussels.

Hill, C. 1993. The capability-expectations gap, or conceptualizing Europe's international role. JCMS: Journal of Common Market Studies 31, no. 3: 305-328.

Hoffmann, S. 2000. Towards a common European foreign and security policy? JCMS: Journal of Common Market Studies 38, no. 2: 189-198.

Howorth, J. 2010. The EU as a global actor: grand strategy for a global grand bargain? JCMS: Journal of Common Market Studies 48, no. 3: 455-474.

Hyde-Price, A. 2007. European security in the twenty-first century. London: Routledge.

Hyde-Price, A. 2008. A 'tragic actor'? A realist perspective on 'ethical power Europe'. International Affairs 84 , no. 1:29-44.

Jones, S.G. 2007. The rise of European security cooperation. Cambridge: Cambridge University Press.

Kenealy, D., and K. Kostagiannis. 2013. Realist visions of European Union: E.H. Carr and integration. Millennium: Journal of International Studies 41, no. 2: 221-246.

Lang Jr., A. 2007. Morgenthau, agency, and Aristotle. In Realism reconsidered. The legacy of Hans J. Morgenthau in international relations, ed. M.C. Williams, 18-41. Oxford: Oxford University Press.

Mahoney, D. 1992. The liberal political science of Raymond Aron. A critical introduction. Lanham: Rowman \& Littlefield.

Manners, I. 2002. Normative power Europe: A contradiction in terms? JCMS: Journal of Common Market Studies 40, no. 2: 235-258.

Manners, I. 2008. The normative ethics of the European Union. International Affairs 84, no. 1: 45-60.

Manners, I. 2015. Sociology of knowledge and production of normative power in the European Union's external actions. Journal of European Integration 37, no. 2: 299-318.

Mearsheimer, J. 2001. The future of the American pacifier. Foreign Affairs 80, no. 5: 46-61.

Menon, A. 2014. The JCMS annual review lecture. Divided and declining? Europe in a changing World. JCMS: Journal of Common Market Studies 52: 5-24.

Merlingen, M. 2012. EU security policy. What it is, how it works, why it matters. London: Lynne Rienner.

Missiroli, A. 2015. The EU in a multiplex World. EU-ISS Brief Issue No. 7.

Molloy, S. 2006. The hidden history of realism. A genealogy of power politics. Basingstoke: Palgrave Macmillan.

Morgan, G. 2005. Realism and European political integration: the lessons of the United States. European Political Science 4: 199-208.

Morgenthau, H. (1993[1948]). Politics among Nations. The struggle for power and peace. London: McGrawHill.

Neumann, I.B., and H. Heikka. 2005. Grand strategy, strategic culture, practice: the social roots of nordic defence. Cooperation and Conflict 40, no. 1: 5-23.

Peters, D. 2010. Constrained balancing: the EU's security policy. Basingstoke: Palgrave Macmillan.

Posen, B.R. 2006. European Union security and defense policy: response to unipolarity? Security Studies 15, no. 2: 149-186.

Pram Gad, U., and K. Lund Petersen. 2011. Concepts of politics in securitization studies. Security Dialogue 42, no. 4-5: 315-328.

Risse, T. 2010. A community of Europeans? Transnational identities and public spheres. Ithaca, NY: Cornell University Press. 
Rosato, S. 2010. Europe united: power politics and the making of the European community. Ithaca, NY: Cornell University Press.

Rosenthal, J.H. 1999. Introduction: Ethics through the cold war and after. In Ethics \& international affairs. A reader, ed. J.H. Rosenthal, 1-7. Washington, DC: Georgetown University Press.

Rynning, S. 2005. Return of the Jedi: realism and the study of the European Union. Political science publications 9/2005. University of Southern Denmark: 1-36.

Rynning, S. 2011. Realism and the common security and defence policy. JCMS: Journal of Common Market Studies 49, no. 1:23-42.

Scheuerman, W.E. 2009. Morgenthau. Cambridge: Polity Press.

Scheuerman, W.E. 2010. The (classical) realist vision of global reform. International Theory 2, no. 2: 246-282.

Scheuerman, W.E. 2011. The realist case for global reform. Cambridge: Polity.

Smith, M.E. 2011. A liberal grand strategy in a realist world? Power, purpose and the EU's changing global role. Journal of European Public Policy 18, no. 2: 144-163.

Snyder, J. 2011. Tensions within realism: 1954 and after. In The invention of international relations theory. Realism, the Rockefeller Foundation, and the 1954 conference on theory, ed. N. Guilhot, 54-78. New York: Columbia University Press.

Stokes, D., and R.G. Whitman. 2013. Transatlantic triage? European and UK'grand strategy' after the US rebalance to Asia. International Affairs 89, no. 5: 1087-1107.

Tjalve, V.S. 2008. Realist strategies of Republican Peace. Niebuhr, Morgenthau, and the politics of patriot dissent. Basingstoke: Palgrave.

Tjalve, V.S. 2011. Designing (de)security: European exceptionalism, Atlantic republicanism and the 'public sphere'. Security Dialogue 42, no. 4-5: 441-452.

Wæver, Ole. 2011. The speech act of realism: the move that made IR. In The invention of international relations theory. Realism, the Rockefeller Foundation, and the 1954 conference on theory, ed. N. Guilhot, 97-126. New York: Columbia University Press.

Waltz, K. 1979. Theory of international politics. New York: McGraw-Hill.

Whitman, R. 1998. From civilian power to superpower? The international identity of the European Union. Basingstoke: Macmillan.

Williams, M.C. 2005. The realist tradition and the limits of international relations. Cambridge: Cambridge University Press.

Williams, M.C. 2010. The legacies of raison d'etat: a brief commentary on R. Harrison Wagner's War and the State. International Theory 2, no. 2: 306-316.

Williams, M.C. 2011. Securitization and the liberalism of fear. Security Dialogue 42, no. 4-5: 453-463.

Witney, N. 2008. Re-energising Europe's security and defence policy. Policy paper, European Council on foreign relations. London: European Council on Foreign Relations.

Witney, N., Leonard, M., Godement, F., Levy, D., Liik, K., Tcherneva, V. 2014. Rebooting EU foreign policy, ECFR Policy Brief No. 114. 